\title{
The effect of microstructural features on the mechanical properties of LZSA glass-ceramic matrix composites
}

\section{(Efeito das características microestruturais nas propriedades mecânicas de compósitos baseados em matriz vitrocerâmica do sistema LZSA)}

\author{
F. M. Bertan ${ }^{1}$, A. P. Novaes de Oliveira ${ }^{2}$, O. R. K. Montedo ${ }^{*}$, D. Hotza ${ }^{2}$, C. R. Rambo ${ }^{2}$ \\ ${ }^{1}$ Unidade Acadêmica de Ciências, Engenharias e Tecnologia - UNACET, Universidade do Extremo Sul \\ Catarinense, UNESC, Av. Universitária 1105, P.O. Box 3167, Criciúma, SC, Brazil 88.806-000 \\ ${ }^{2}$ Group of Ceramic and Glass Materials - CERMAT, Federal University of Santa Catarina - UFSC, \\ Florianópolis, SC, Brazil \\ fmb@unesc.net,oscar.rkm@gmail.com*,pedronovaes@emc.ufsc.br,dhotza@gmail.com,rambo@enq.ufsc.br \\ *Corresponding author
}

\begin{abstract}
This work reports on the characterization of $\mathrm{ZrSiO}_{4}$ particulate-reinforced $\mathrm{Li}_{2} \mathrm{O}-\mathrm{ZrO}_{2}-\mathrm{SiO}_{2}-\mathrm{Al}_{2} \mathrm{O}_{3}$ (LZSA) glass-ceramic matrix composites. The typical physical/mechanical and chemical properties of the glass batches and the composites were measured. A composition with $60 \mathrm{wt} . \% \mathrm{ZrSiO}_{4}$ was preliminarily selected because it demonstrated the highest values of bending strength (190 $\mathrm{MPa}$ ) and deep abrasion resistance $\left(51 \mathrm{~mm}^{3}\right)$. To this same composition was given a $7 \mathrm{wt} \%$ bentonite addition in order to obtain plasticity behavior suitable for extrusion. The sintered samples $\left(1150{ }^{\circ} \mathrm{C}\right.$ for $\left.10 \mathrm{~min}\right)$ presented a thermal linear shrinkage of $14 \%$ and bending strength values of $220 \mathrm{MPa}$.
\end{abstract}

Keywords: glasses, ceramic-matrix composites, mechanical properties, extrusion.

\section{Resumo}

Este trabalho relata a caracterização de compósitos baseados em matriz vitrocerâmica do sistema $\mathrm{Li}_{2} \mathrm{O}_{-} \mathrm{ZrO}_{2}-\mathrm{SiO}_{2}-\mathrm{Al}_{2} \mathrm{O}_{3}(\mathrm{LZSA})$ reforçados com partículas de $\mathrm{ZrSiO}_{4}$. As propriedades físicas/mecânicas e químicas típicas das bateladas de vidros e dos compósitos foram medidos. Uma composição com $60 \%$ em peso de $\mathrm{ZrSiO}_{4}$ foi inicialmente selecionada por ter demonstrado elevados valores de resistência à flexão (190 MPa) e resistência à abrasão profunda $\left(51 \mathrm{~mm}^{3}\right)$. Para esta mesma composição foi adicionado $7 \%$ em peso de bentonita a fim de se obter um comportamento de plasticidade adequado para extrusão. As amostras sinterizadas $\left(1150{ }^{\circ} \mathrm{C}\right.$ por $10 \mathrm{~min}$ ) apresentaram uma retração térmica linear de $14 \%$ e valores de resistência à flexão de $220 \mathrm{MPa}$.

Palavras-chave: vidros, compósitos de matriz cerâmica, propriedades mecânicas, extrusão.

\section{INTRODUCTION}

Composite materials are of interest because they offer the possibility to combine the properties of each constitutive phase to obtain materials with intermediate, appropriate properties for specific applications at low cost. Thus, depending on the selected composite system, and in particular on the reinforcing phase, the cost of the produced material can be considerably varied. For example, platelet, whisker and fiber reinforcements are more expensive than particulate reinforcements [1].

Glass-ceramics are polycrystalline solids that contain a residual glassy phase prepared by melting glass and forming it into products that are subjected to controlled crystallization such that they possess a valuable combination of the favorable properties of both glasses and ceramics [2, 3]. Since Stookey's discovery in 1959 [2, 3], many glassceramic systems have been developed and produced as components for a variety of applications, such as cooktops, cookware and bakeware, protective layers, and sewing-thread supports for the textile industry [2-4]. Such interest is related to the possibility of designing glass-ceramic materials with specific properties. Depending on the chemical composition and the applied thermal cycle, the resulting crystals may vary in size, possessing intrinsic properties that may change within a wide range; for example, the thermal expansion of such a material may be negative, positive or approximately zero. Glass-ceramics are intrinsic composites because the reinforcing phase is nucleated from the parent glass during the thermal treatment. For this reason, glass-ceramic materials tend to exhibit, for example, higher toughness and mechanical strength values than glasses. Hence, glassceramics have been used as the matrix phase to produce composites reinforced with platelets, fibers or particles [1, 5-10], replacing the use of glass matrices.

Generally, metals and polymers are used as matrix 
materials, especially in cases where a certain amount of ductility is desirable. With respect to ceramic matrix composites, the reinforcing component is introduced to enhance the fracture toughness $\left(\mathrm{K}_{\mathrm{Ic}}\right)$, which is typically low for ceramic materials ( 1 to $5 \mathrm{MPa}(\mathrm{m})^{1 / 2}$, while most metals have $\mathrm{K}_{\mathrm{Ic}}$ values between 15 and $150 \mathrm{MPa}(\mathrm{m})^{1 / 2}$ [11]). However, ceramic matrix composites reinforced with ceramic fibers or whiskers may present $\mathrm{K}_{\mathrm{Ic}}$ values from 6 to $20 \mathrm{MPa}(\mathrm{m})^{1 / 2}$ [11]. For glasses and glass-ceramics those values range from 0.6 to 0.9 or up to $3.0 \mathrm{MPa}(\mathrm{m})^{1 / 2}$, respectively $[2,3]$. Glass-ceramics belonging to the $\mathrm{Li}_{2} \mathrm{O}-$ $\mathrm{Al}_{2} \mathrm{O}_{3}-\mathrm{SiO}_{2}$ (LAS) system exhibit fracture toughness values of $1.5 \mathrm{MPa}(\mathrm{m})^{1 / 2}$ [1]. However, for LAS glass-ceramic matrix composites reinforced with 46 vol.\% SiC fibers, the values have been found to be approximately $17 \mathrm{MPa}(\mathrm{m})^{1 / 2}$ [1]. The bending strength values of LAS glass-ceramics range from 180 to $830 \mathrm{MPa}$ when reinforced with SiC fibers [1]. However, particulate glass-ceramic matrix composites show better thermal shock resistance [1] and are indicated for applications involving abrasive wear. They are lighter than metals and are more thermally stable than polymers. Moreover, glass-ceramic materials, especially those obtained from glass powders (sintered glass-ceramics), can be economically produced from industrial raw materials at relatively low temperatures $\left(700-1200{ }^{\circ} \mathrm{C}\right)$.

Among the investigated sintered glass-ceramic systems, LZSA $\left(\mathrm{Li}_{2} \mathrm{O}-\mathrm{ZrO}_{2}-\mathrm{SiO}_{2}-\mathrm{Al}_{2} \mathrm{O}_{3}\right)$ has been widely studied [12-23]. This glass-ceramic exhibits several properties of technological interest, due to the primary crystalline phases formed ( $\beta$-spodumene solid solution, $\mathrm{Li}_{2} \mathrm{O} \cdot \mathrm{Al}_{2} \mathrm{O}_{3} \cdot 4-10 \mathrm{SiO}_{2}$ and zircon, $\mathrm{ZrSiO}_{4}$ ), such as a relatively high bending strength (up to $110 \mathrm{MPa}$ ), good abrasion and chemical resistances and coefficients of thermal expansion between 4.6 and 9.1 x $10^{-6}{ }^{\circ} \mathrm{C}^{-1}$, depending on the chemical composition and processing technique. The magnitude of these properties makes the LZSA glass-ceramic system important for many applications, including coatings for the improvement of abrasive wear resistance, filters and electronic packages with dielectric constants between 8 and $9(1 \mathrm{MHz}$ at room temperature) performed on LZSA glass-ceramic crystallized laminates.

A large number of reinforcements, such as fibers and particles, are available in the market. In selecting a reinforcing phase, several basic requirements must be followed to obtain ceramic matrix composites (CMCs) with appropriate properties for the given application.

In the present work, a LZSA glass-ceramic composition was selected as the matrix. Additionally, the properties of improved mechanical strength and abrasion wear were expected, while the toughness was of minor importance; hence, a particulate reinforcement was selected. In this case, zircon $\left(\mathrm{ZrSiO}_{4}\right)$ was selected as the reinforcing phase due to its excellent chemical and thermal stabilities as well as its thermal shock resistance $[12,24]$ and low thermal expansion coefficient $\left(4.1 \times 10^{-6} \mathrm{C}^{-1}\right)$ up to $1400^{\circ} \mathrm{C}[11,25]$. Moreover, zircon was selected because it shows a relatively high hardness (9-10 GPa) and bending strength (320 MPa), according to measurements conducted by Shi et al. [25] in high purity hot-pressed zircon ceramics.

The previous remarks indicate that it is of vital importance to reduce production costs and to make ceramic manufacturing processes more flexible. However, the essential requirements for structural ceramics and ceramic composites are high temperature stability, oxidation resistance and damage tolerance [26]. Therefore, glassceramic matrix composites reinforced with particles or short, randomly distributed fibers may be an economically interesting alternative because these materials can be fabricated with the same processing technologies that are already available for ceramic fabrication.

Several processing techniques have been studied to produce glass-ceramics from glass powders, such as extrusion [4], injection molding [12] and roll-pressing [14]. Extrusion is a very useful powder forming technique, and for this reason, it is often used for the mass production of components with either small or large dimensions. Substrates such as extruded components can be obtained at low costs, with thicknesses less than $1 \mathrm{~mm}$ and in complex shapes [27].

Plasticity, a property that vitreous materials and many ceramics do not exhibit, is the ability of a material or a powder compact to be deformed without rupture by the action of an applied force as well as to retain the absorbed deformation when an applied force is removed [27, 28]. This property is a decisive factor for the extrusion process, and it directly interferes in the quality of the extruded products. To provide plasticity to a ceramic material, organic or inorganic binders are used. The use of organic binders can increase the processing cost because they require a long thermal cycle for removal. Moreover, there is the possibility of defect generation, such as internal porosity and cracks caused by the decomposition of carbon residues. Inorganic binders can be an alternative solution to these problems; for example, bentonite is incorporated into the base material studied here.

In this context, this article reports the details of the production process and the typical properties of the raw materials and the zircon particulate-reinforced LZSA glassceramic matrix composites prepared with bentonite as the binder and formed by extrusion. The mechanical properties were measured, and the microstructural parameters were analyzed to gain a better understanding of the controlling and limiting factors of abrasive wear resistance and mechanical strength, providing the necessary understanding for the development of glass-ceramic matrix composites (GCMCs) with high performance.

\section{EXPERIMENTAL}

The LZSA glass was produced by Colorminas (Brazil) from commercially available raw materials $\left(\mathrm{Li}_{2} \mathrm{CO}_{3}, \mathrm{ZrSiO}_{4}\right.$ and $\mathrm{SiO}_{2}$ and $\mathrm{LiAlSi}_{2} \mathrm{O}_{6}$, spodumene). A $300 \mathrm{~kg}$ batch was loaded in a gas furnace and melted at $1500{ }^{\circ} \mathrm{C}$ for $7 \mathrm{~h}$. The melt was quenched in water and dried. The obtained glass frit was dry-crushed in an agate ball mill for $15 \mathrm{~min}$ and then sieved to yield a powder measuring $<200 \mu \mathrm{m}$ in 
Table I - The chemical compositions and theoretical densities $\left(\rho_{t}\right)$ of the LZSA parent glass (frit), the bentonite and the zircon $\left(\mathrm{ZrSiO}_{4}\right)$.

[Tabela I - Composições químicas e densidades teóricas $\left(\rho_{t}\right)$ do vidro precursor LZSA (frita), da bentonita e do silicato de zircônio $\left(\mathrm{ZrSiO}_{4}\right)$.]

\begin{tabular}{lccc}
\hline \multirow{2}{*}{$\begin{array}{c}\text { Constitutive } \\
\text { oxide }\end{array}$} & \multicolumn{3}{c}{ Chemical composition (wt.\%) } \\
\cline { 2 - 4 } & LZSA glass frit & Zircon & Bentonite \\
\hline $\mathrm{SiO}_{2}$ (total) & 59.4 & 32.2 & 62.8 \\
Free silica & - & 0.05 & - \\
$\mathrm{ZrO}_{2}+\mathrm{HfO}_{2}$ & - & 66.0 & - \\
$\mathrm{ZrO}_{2}$ & 15.6 & - & - \\
$\mathrm{Al}_{2} \mathrm{O}_{3}$ & 13.6 & 0.80 & 20.3 \\
$\mathrm{Li}_{2} \mathrm{O}$ & 8.60 & - & - \\
$\mathrm{Na}_{2} \mathrm{O}$ & 0.70 & - & 2.40 \\
$\mathrm{~K}_{2} \mathrm{O}$ & 0.30 & - & 0.50 \\
$\mathrm{CaO}_{\mathrm{Oa}}$ & 0.60 & $<0.10$ & 1.20 \\
$\mathrm{Fe}_{2} \mathrm{O}_{3}$ & 0.20 & 0.11 & 3.80 \\
$\mathrm{TiO}_{2}$ & 0.10 & 0.06 & 0.10 \\
$\mathrm{P}_{2} \mathrm{O}_{5}$ & 0.82 & 0.10 & 0.20 \\
$\mathrm{Nb}_{2} \mathrm{O}_{5}$ & - & $<0.10$ & - \\
$\mathrm{MnO}_{\mathrm{MgO}}$ & - & $<0.05$ & $<0.10$ \\
$\mathrm{Theoretical}_{\text {density, }}$ & 0.02 & $<0.05$ & 2.30 \\
$\rho_{\mathrm{t}}\left(\mathrm{g} / \mathrm{cm}^{3}\right)$ & 2.63 & 4.70 & 2.49 \\
\hline & & & \\
\hline
\end{tabular}

Table II - The LZSA glass frit and the zircon $\left(\mathrm{ZrSiO}_{4}\right)$ fractions of the prepared compositions.

[Tabela II - Teores da frita LZSA e de silicato de zircônio $\left(\mathrm{ZrSiO}_{4}\right)$ das composições preparadas.]

\begin{tabular}{cccc}
\hline Composition & $\begin{array}{c}\text { LZSA } \\
\text { content } \\
{[\mathrm{wt} . \%]}\end{array}$ & $\begin{array}{c}\mathrm{ZrSiO}_{4} \\
\text { content } \\
{[\mathrm{wt} . \%]}\end{array}$ & $\begin{array}{c}\text { Volume fraction, } \\
\mathrm{V}_{\beta} \text { of } \mathrm{ZrSiO}_{4} \\
{[-]}\end{array}$ \\
\hline $\mathbf{A}$ & 100 & 0 & 0.000 \\
$\mathbf{B}$ & 90 & 10 & 0.063 \\
$\mathbf{C}$ & 80 & 20 & 0.123 \\
$\mathbf{D}$ & 70 & 30 & 0.194 \\
$\mathbf{E}$ & 60 & 40 & 0.273 \\
$\mathbf{F}$ & 50 & 50 & 0.360 \\
$\mathbf{G}$ & 40 & 60 & 0.458 \\
$\mathbf{H}$ & 30 & 70 & 0.568 \\
\hline
\end{tabular}

particle size. The crushed glass was milled in an aluminous porcelain mill containing alumina grinding media and water, resulting in an average particle size of $2.5 \mu \mathrm{m}$. To obtain the composite compacts by extrusion, 10 to $70 \mathrm{wt} . \%$ $\mathrm{ZrSiO}_{4}$ (approximately $4.5 \mu \mathrm{m}$ mean particle diameter) in $10 \%$ intervals between each composition, and 7 wt.\% bentonite (approximately $2.8 \mu \mathrm{m}$ mean particle diameter), both supplied by Colorminas (Brazil), were added to the glass powder, mixed and humidified with water (23 wt.\%). The chemical analyses of the raw materials and the LZSA frit, obtained by atomic absorption spectroscopy (AA) (Unicam Solaar 969, Cambridge, United Kingdom) and X-ray fluorescence spectroscopy (XRF) (Philips PW 2400, Eindhoven, The Netherlands), are presented in Table I. The theoretical densities are also included in Table I. The average particle sizes were determined using a laser scattering particle size analyzer (CILAS 1064L, Orleans, France). Table II shows the LZSA frit and $\mathrm{ZrSiO}_{4}$ fractions of the prepared compositions. Subsequently, the mixtures were stored for $12 \mathrm{~h}$ to allow for moisture homogenization and then were continuously extruded in a Netzsch extruder (MA 01, Selb, Germany) and cut into compact samples with nominal dimensions of $80 \mathrm{~mm}$ (length) $\times 25 \mathrm{~mm}$ (width) $\times$ $5 \mathrm{~mm}$ (thickness). After $48 \mathrm{~h}$ at $20^{\circ} \mathrm{C}$, the extruded samples were dried at $110{ }^{\circ} \mathrm{C}$ and then were isothermally sintered in an electric furnace in air at a heating rate of $10{ }^{\circ} \mathrm{C} \cdot \mathrm{min}^{-1}$ for $10 \mathrm{~min}$ at temperatures in the range of $500-1300{ }^{\circ} \mathrm{C}$. After sintering, the samples were air-quenched to room temperature.

To define the optimum reinforcing fraction, according to densification, deep abrasion resistance and bending strength, the glass powder and appropriated zircon amounts (10-70 wt.\%) were wet mixed (a water content of 9 wt.\%) and uniaxially pressed at $40 \mathrm{MPa}$ in a steel die. Compacted samples, with nominal dimensions of $100 \mathrm{~mm} \times 50 \mathrm{~mm} \times$ $10 \mathrm{~mm}$, were obtained and then were dried at $110^{\circ} \mathrm{C}$ for 2 h. The thermal linear shrinkage (TLS) and the coefficient of thermal expansion (CTE) of the compacted samples were measured using a dilatometer (Netzsch dilatometer Model DIL 402PC, Selb, Germany) at $10{ }^{\circ} \mathrm{C} \cdot \mathrm{min}^{-1}$ in air, with alumina as the reference material, for rectangular samples of $20 \mathrm{~mm}$ in length, $5 \mathrm{~mm}$ in width and $5 \mathrm{~mm}$ in thickness. The theoretical densities $\left(\rho_{\mathrm{t}}\right)$ of the sintered samples (using powdered pieces of the samples), the raw materials and the LZSA frit (powdered samples) were measured by Hepycnometry (AccuPyc 1330, Micromeritics, Norcross, GA; 5 measurements). The apparent density $\left(\rho_{\mathrm{ap}}\right)$ was measured by the Archimedes principle by water immersion at $20^{\circ} \mathrm{C}$. The relative density $\left(\rho_{\mathrm{r}}\right)$ was calculated from the relationship between the theoretical density and the apparent density, according to eq. A:

$$
\rho_{\mathrm{r}}=\rho_{\mathrm{ap}} / \rho_{\mathrm{t}}
$$

After sintering, the samples were transversely cut, ground and polished with $1-\mu \mathrm{m}$ alumina paste. Subsequently, all samples were coated with a thin Au film for the scanning electron microscopy (SEM) observations (Philips XL 30, Eindhoven, The Netherlands). Using Fullman's eq. B and $C$ [29], the interfacial area and the mean free path were calculated, respectively:

$$
\mathrm{S}_{\alpha \beta}=6 \mathrm{~V}_{\beta} / \mathrm{d}_{\beta}
$$


where $S_{\alpha \beta}$ is the total interfacial area $\left(\mu \mathrm{m}^{2} / \mu \mathrm{m}^{3}\right)$ formed by the matrix $(\alpha)$ and by the dispersed or reinforcing phase $(\beta)$ and $\mathrm{V}_{\beta}(-)$ and $\mathrm{d}_{\beta}(\mu \mathrm{m})$ are, respectively, the volume fraction and the average diameter of the dispersing phase. The dispersion of the second phase can be calculated, and thus indirectly controlled, by eq. B through eq. C:

$$
\lambda=2 \mathrm{~d}_{\beta}\left(1-\mathrm{V}_{\beta}\right) / 3 \mathrm{~V}_{\beta}
$$

where $\lambda$ is the mean free path between the dispersed particles. The bending strength $\left(\sigma_{f}\right)$ of the sintered samples was determined in a test machine (Model DL 2000, EMIC, São José dos Pinhais, Brazil) according to ISO 10545-4, which consisted of a three-point test on six samples with dimensions of $100 \mathrm{~mm} \times 50 \mathrm{~mm} \times 10 \mathrm{~mm}$ at a load rate of $1 \mathrm{MPa} \cdot \mathrm{s}^{-1}$. The composite properties depend on the intrinsic properties of the constitutive phases, their relative quantities and morphologies, sizes and distributions. The mechanical strength, with respect to the phase volume fractions of the composites, was estimated according to eq. D:

$$
\sigma_{f}=\sigma_{\alpha} \cdot V_{\alpha}+\sigma_{\beta} \cdot V_{\beta}
$$

where $\sigma_{\mathrm{f}}$ is the calculated bending strength (MPa) of the composite, $\sigma_{\alpha}$ and $\sigma_{\beta}$ are, respectively, the ultimate bending strength of the matrix and the reinforcing phase and $\mathrm{V}_{\alpha}$ and $\mathrm{V}_{\beta}$ are the volume fractions of the matrix and the reinforcing phase, respectively. The deep abrasion $\left(\mathrm{D}_{\mathrm{a}}\right)$ tests of the sintered samples were performed (test machine Model CAP, Gabrielli, Sassuolo, Italy) according to ISO 10545-6. The deep abrasion values were determined by measuring the volume of material lost after testing, which consisted of an iron disc (360A) with a diameter of $200 \mathrm{~mm}$ and a thickness of $10 \mathrm{~mm}$ rotating over the sample at $75 \mathrm{rpm}$ for 150 revolutions, using $\mathrm{Al}_{2} \mathrm{O}_{3}$ powder ( 80 mesh) as the abrasive medium. The microhardness measurements were performed with a Vickers automatic hardness tester equipped with a diamond Vickers indenter at a load of $4.9 \mathrm{~N}$. A total time of $15 \mathrm{~s}$ was used for each indentation. Each value of hardness is the average of 10 measurements with the respective standard deviation.

\section{RESULTS AND DISCUSSION}

According to the thermal linear shrinkage (TLS) measurements, the densification of the material was apparently affected by the zircon additions. As zircon was added, the thermal shrinkage decreased, and the shrinkage rate for all studied compositions tended to zero as the temperature was increased. This behavior is related to the reduction in the formed viscous liquid phase as the zircon was added [29]. Therefore, samples of each formulated composite were sintered at different temperatures; however, in each case, the temperature corresponded to a value for which the shrinkage rate achieved was a maximum (the maximum relative density, as shown in Table III). The calculated microstructural parameters and properties of the uniaxially compacted sintered samples are shown in Table III.

Fig. 1 shows the relative density as a function of the $\mathrm{ZrSiO}_{4}$ content in the composites. A slight increase in the porosity $(5 \%)$ was observed with increasing $\mathrm{ZrSiO}_{4}$ content, according to the calculated relative density values. The porosity tended to be constant (approximately 9\%) for compositions with a $\mathrm{ZrSiO}_{4}$ content between 40 wt.\% $\left(\mathrm{V}_{\beta}=0.27\right)$ and $70 \mathrm{wt} . \%\left(\mathrm{~V}_{\beta}=0.57\right)$. While sintering the glassy matrix, gas (bubbles) must be released from the bulk material, and their outward mobility is limited by the presence of the $\mathrm{ZrSiO}_{4}$ crystals. Therefore, the amount of total porosity was proportional to the amount of the $\mathrm{ZrSiO}_{4}$ crystals.

Table III - The calculated microstructural parameters and properties of the formulated and prepared materials sintered at selected temperatures $(\mathrm{T})$ for $10 \mathrm{~min}$.

[Tabela III - Parâmetros microestruturais calculados e propriedades dos materiais formulados e preparados, sinterizados nas temperaturas selecionadas (T) por $10 \mathrm{~min}$.

\begin{tabular}{ccccccc}
\hline Composition & $\begin{array}{c}\mathrm{T} \\
\left({ }^{\circ} \mathrm{C}\right)\end{array}$ & $\begin{array}{c}\mathrm{V}_{\beta} \\
(-)\end{array}$ & $\begin{array}{c}\lambda \\
(\mu \mathrm{m})\end{array}$ & $\begin{array}{c}\mathrm{S}_{\alpha \beta} \\
\left(\mu \mathrm{m}^{2} / \mu \mathrm{m}^{3}\right)\end{array}$ & $\begin{array}{c}\rho_{\mathrm{r}} \\
(\%)\end{array}$ & $\begin{array}{c}* \sigma_{\mathrm{f}} \\
(\mathrm{MPa})\end{array}$ \\
\hline $\mathbf{A}$ & 725 & 0.000 & - & - & 94.5 & - \\
$\mathbf{B}$ & 950 & 0.063 & 45 & 0.084 & 93.6 & 76 \\
$\mathbf{C}$ & 950 & 0.123 & 22 & 0.164 & 92.8 & 92 \\
$\mathbf{D}$ & 950 & 0.194 & 13 & 0.259 & 91.5 & 110 \\
$\mathbf{E}$ & 1100 & 0.273 & 8 & 0.364 & 89.8 & 131 \\
$\mathbf{F}$ & 1125 & 0.360 & 5 & 0.480 & 89.3 & 154 \\
$\mathbf{G}$ & 1200 & 0.458 & 4 & 0.611 & 91.2 & 179 \\
$\mathbf{H}$ & 1300 & 0.568 & 2 & 0.757 & 90.8 & 208 \\
\hline
\end{tabular}

$V_{\beta}=$ volume fraction of zircon; $\lambda=$ mean free path between the reinforcing particles calculated by eq. $C ; S_{\alpha \beta}=$ total interface area (eq. B); $\rho_{r}=$ relative density (by density measurements, eq. A); ${ }^{*} \sigma_{f}=$ bending strength calculated by eq. $D$ (60 MPa for composition LZSA and 320 MPa for pure zircon) 


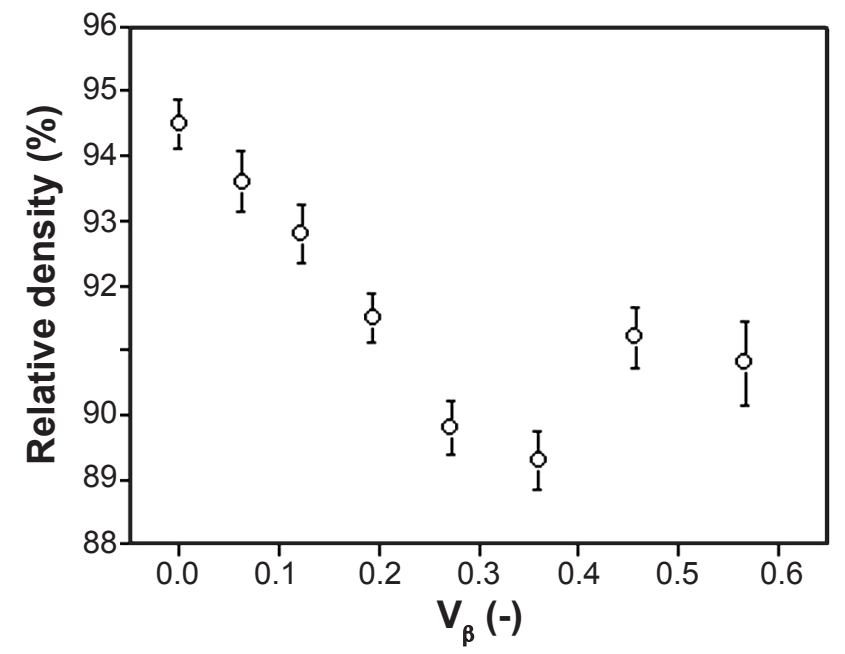

Figure 1: Relative density as a function of the $\mathrm{ZrSiO}_{4}$ content in the composites.

[Figura 1: Densidade relativa em função do conteúdo de $\mathrm{ZrSiO}_{4}$ nos compósitos.]

The deep abrasion $\left(D_{a}\right)$ values were affected by the zircon particle additions, decreasing from composition $\mathrm{A}$ to composition $\mathrm{B}$ and then increasing from composition $\mathrm{B}$ to composition D (Fig. 2). Although relative scatter is present in the data, the resistance to deep abrasion tended to decrease with an increasing $\mathrm{ZrSiO}_{4}$ fraction.

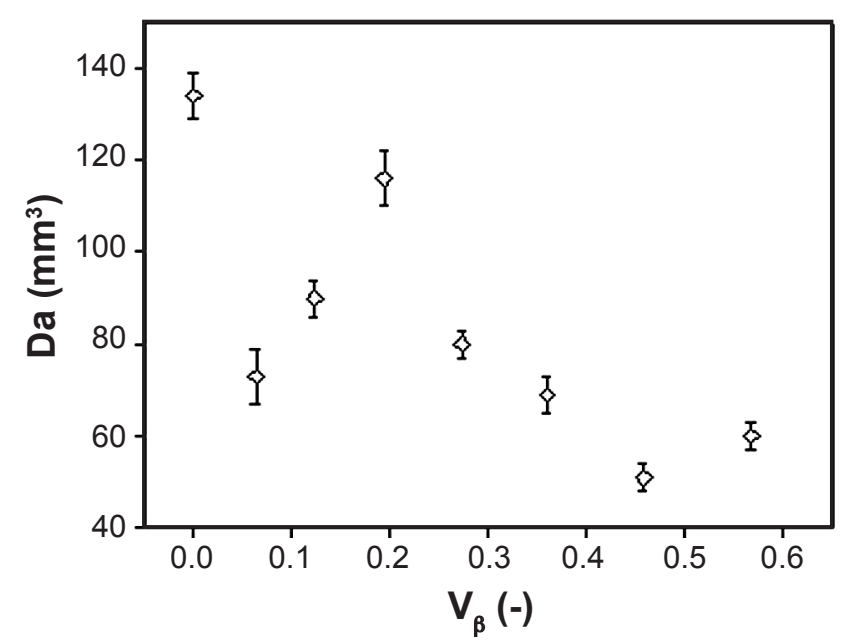

Figure 2: Deep abrasion $\left(\mathrm{D}_{\mathrm{a}}\right)$ as a function of the $\mathrm{ZrSiO}_{4}$ content in the composites.

[Figura 2: Abrasão profunda $\left(D_{d}\right)$ em função do conteúdo de $\mathrm{ZrSiO}_{4}$ nos compósitos.]

This was probably due to the homogeneity of the dispersed $\mathrm{ZrSiO}_{4}$ crystals. By comparing composition B and composition $\mathrm{E}$, for example, it can be observed that the deep abrasion resistance decreased, even for higher zircon contents. However, composition $\mathrm{B}$, with $10 \mathrm{wt} . \% \mathrm{ZrSiO}_{4}$ $\left(\mathrm{V}_{\beta}=0.063\right)$, exhibited lower porosity than composition $\mathrm{E}\left(40\right.$ wt. $\% \mathrm{ZrSiO}_{4}$ ), which indicated a higher degree of densification and therefore a more homogeneous surface, resulting in lower abrasion. This occurred because the $\mathrm{Li}_{2} \mathrm{O}-$
$\mathrm{ZrO}_{2}-\mathrm{SiO}_{2}-\mathrm{Al}_{2} \mathrm{O}_{3}$ glassy phase content in composition $\mathrm{B}$ was higher, which yielded, as a consequence, a higher amount of viscous liquid phase at the sintering temperature. The abrasion resistance was not entirely dependent on the hardness of the reinforcement particles but on their shape and distribution within the matrix and on the particle/ matrix interaction [30]. In fact, the estimated interfacial area between the dispersed particles $\left(\mathrm{S}_{\alpha \beta}\right)$ increased as the $\mathrm{ZrSiO}_{4}$ content was increased (Fig. 3).

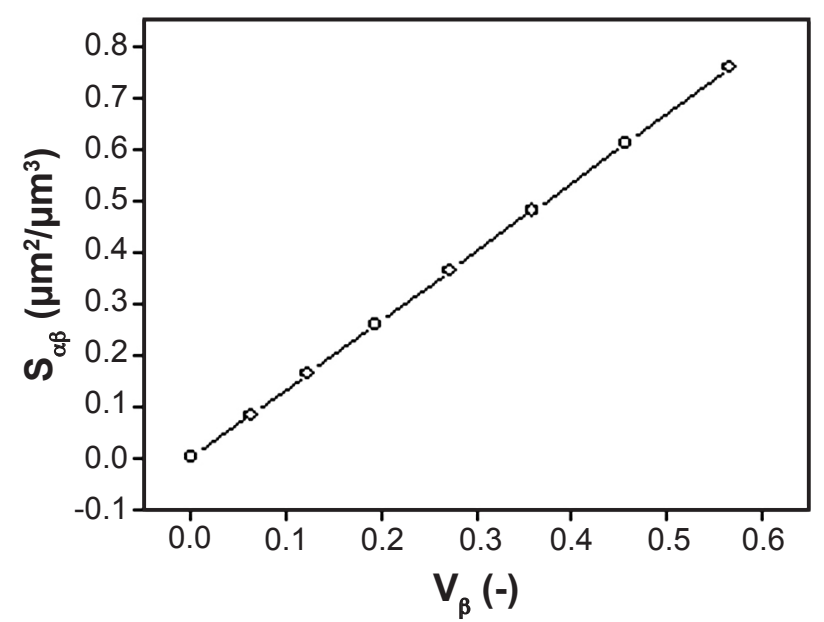

Figure 3: Estimated interfacial area between the dispersed particles $\left(\mathrm{S}_{\alpha \beta}\right)$ as a function of the $\mathrm{ZrSiO}_{4}$ volume fraction.

[Figura 3: Área interfacial estimada entre as partículas dispersas $\left(S_{\alpha \beta}\right)$ em função da fração volumétrica de $\mathrm{ZrSiO}_{4}$.]

Fig. 4 shows the bending strength (Fig. 4a) and the microhardness (Fig. 4b) as functions of the $\mathrm{ZrSiO}_{4}$ content in the composites. The bending strength $\left(\sigma_{f}\right)$ increased from composition A to composition B and then decreased from composition B to composition C. The deep abrasion and bending strength variations resulted from the differences in composition and sintering temperature. The presence of finer grains and lower porosity in composition $\mathrm{G}$ improved the interaction between the matrix and the reinforcement, which resulted in a higher strength (Fig. 4a). A good agreement was found between the measured $\left(\sigma_{\mathrm{f}}\right)$ and calculated $\left({ }^{*} \sigma_{\mathrm{f}}\right)$ bending strength (solid curve).

The microhardness (Hv) values increased for higher zircon contents, particularly for $\mathrm{ZrSiO}_{4}$ contents higher than 60 wt.\% $\left(\mathrm{V}_{\beta}=0.46\right)$, as shown in Fig. 4b. This can be explained by the probability of the indenter (abrasive alumina particles) to contact with a hard phase, which increased with the amount of this phase present, because a lower mean free path $(\lambda)$ was expected for higher contents, as shown in Table III. Composition H showed the highest value $(9.4 \mathrm{GPa})$ due to the higher zircon content and higher sintering temperature. The more significant results of the deep abrasion and bending strength analyses among the studied compositions were related to composition G, sintered at $1200^{\circ} \mathrm{C}$.

Based on the previous results and considering adjustments in the water content and plasticity as well as 

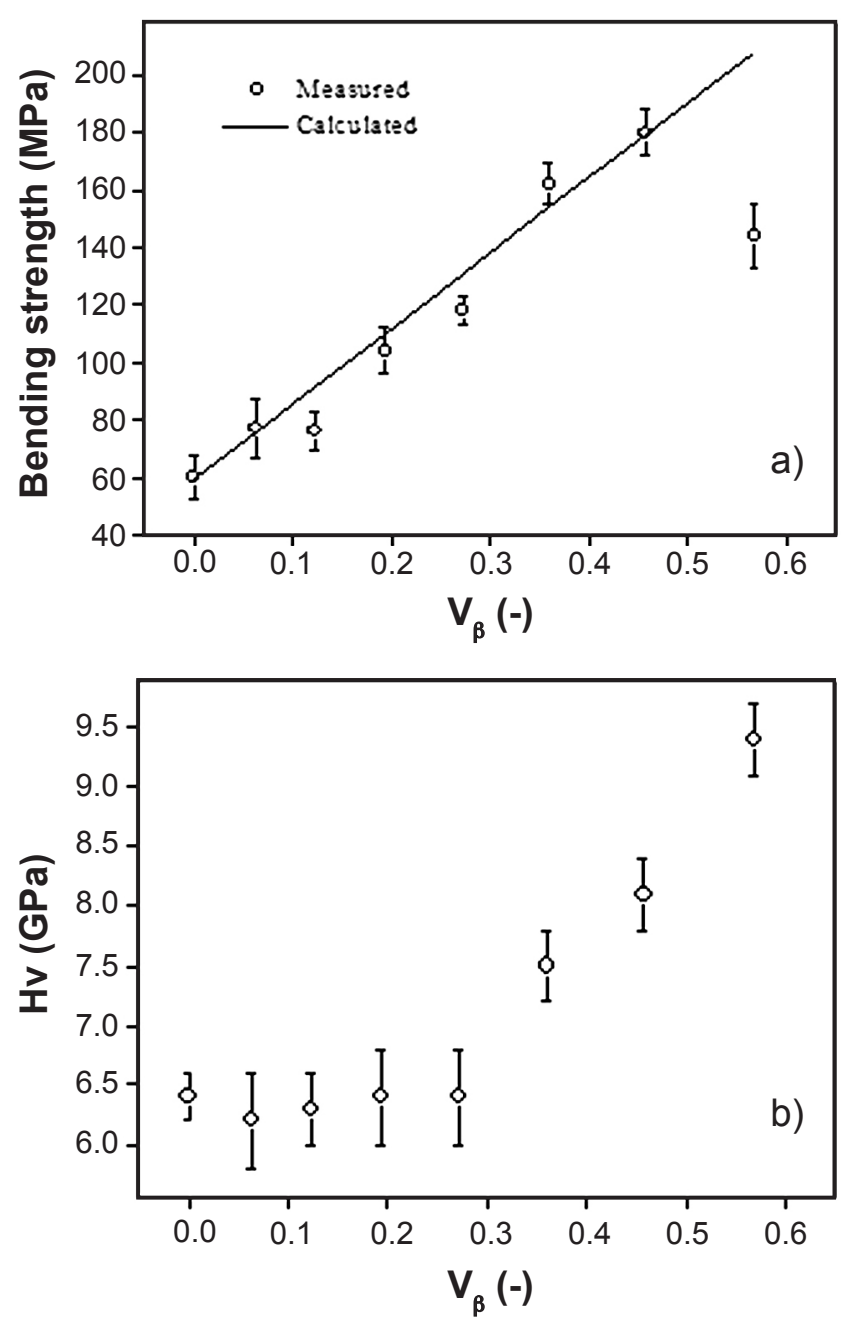

Figure 4: Bending strength (a) and the microhardness (b) as functions of the $\mathrm{ZrSiO}_{4}$ volume fraction.

[Figura 4: Resistência à flexão (a) e microdureza (b) em função da fração volumétrica de $\mathrm{ZrSiO}_{4}$.]

the extrusion die design required to eliminate the extrusion defects, composition $\mathrm{G}$ was selected for further study.

After drying, the extruded samples of composition $G$ exhibited an average apparent density of $2.1 \mathrm{~g} . \mathrm{cm}^{-3}$, which is relatively high due to the zircon phase $\left(4.7 \mathrm{~g} . \mathrm{cm}^{-3}\right)$. The relative density was approximately $64 \%$ for composition $\mathrm{G}$, which indicates that the raw materials and the processing parameters were well adjusted because the relative density of the uniaxially pressed compacts corresponds to $50-55 \%$. These results indicate that the addition of $7 \mathrm{wt} . \%$ bentonite was sufficient to obtain dried extruded materials with suitable strengths for finishing operations in the production line. In comparing the results of composition $G$ without bentonite and with $7 \mathrm{wt} \%$ bentonite, it can be observed that the thermal linear shrinkage was reduced from 16 to $13.5 \%$, and in the same way, the temperature related to the maximum thermal linear shrinkage decreased from 1200 to $1150{ }^{\circ} \mathrm{C}$. This reduction can be associated with the bentonite because it exhibits a relatively high content of alkali and other low-temperature oxides (Table I) that contributed to
Table IV - Relative density $\left(\rho_{\mathrm{r}}\right)$, deep abrasion resistance $\left(\mathrm{D}_{\mathrm{a}}\right)$ and bending strength $\left(\sigma_{\mathrm{f}}\right)$ values for composition $\mathrm{G}$ extruded (60 wt. \% zircon and $7 \mathrm{wt} . \%$ bentonite added to the LZSA frit glass powder and mixed and humidified with $23 \mathrm{wt} . \%$ water) and sintered at different temperatures and times.

[Tabela IV - Valores de densidade relativa $\left(\rho_{p}\right)$, resistência à abrasão profunda $\left(D_{a}\right)$ e resistência à flexão $(\sigma)$ para a composição $G$ extrudada $(60 \%$ em peso de silicato de zircônio e 7\% em peso de bentonita adicionados ao pó de frita LZSA, misturados e umidificados com $23 \%$ em peso de água) e sinterizados a diferentes temperaturas e tempos.]

\begin{tabular}{ccccc}
\hline $\begin{array}{c}\text { Sintering } \\
\text { temperature } \\
\left({ }^{\circ} \mathrm{C}\right)\end{array}$ & $\begin{array}{c}\text { Holding } \\
\text { time } \\
(\mathrm{min})\end{array}$ & $\begin{array}{c}\rho_{\mathrm{r}} \\
(\%)\end{array}$ & $\begin{array}{c}\mathrm{D}_{\mathrm{a}} \\
\left(\mathrm{mm}^{3}\right)\end{array}$ & $\begin{array}{c}\sigma_{\mathrm{f}} \\
(\mathrm{MPa})\end{array}$ \\
\hline \multirow{3}{*}{1125} & 10 & 93.6 & $65 \pm 4$ & $154 \pm 12$ \\
& 20 & 93.0 & $60 \pm 3$ & $177 \pm 8$ \\
& 30 & 93.6 & $57 \pm 4$ & $207 \pm 9$ \\
& 60 & 94.1 & $56 \pm 4$ & $220 \pm 7$ \\
\hline \multirow{3}{*}{1150} & 10 & 94.5 & $51 \pm 3$ & $222 \pm 8$ \\
& 20 & 94.1 & $51 \pm 3$ & $200 \pm 10$ \\
& 30 & 93.5 & $56 \pm 3$ & $198 \pm 9$ \\
& 60 & 93.0 & $57 \pm 4$ & $190 \pm 10$ \\
\hline \multirow{3}{*}{1175} & 10 & 93.2 & $57 \pm 3$ & $201 \pm 7$ \\
& 20 & 93.0 & $58 \pm 4$ & $192 \pm 8$ \\
& 30 & 92.6 & $59 \pm 5$ & $190 \pm 8$ \\
& 60 & 91.2 & $58 \pm 3$ & $188 \pm 8$ \\
\hline
\end{tabular}

the increase in the amount of viscous liquid phase. In fact, according to Table IV, which shows the average values of relative density $\left(\rho_{\mathrm{r}}\right)$, deep abrasion $\left(\mathrm{D}_{\mathrm{a}}\right)$ and bending strength $\left(\sigma_{\mathrm{f}}\right)$ as functions of the sintering temperature and holding time, the relative density at $1150{ }^{\circ} \mathrm{C} / 10$ min was $94.5 \%$, which is higher than that for composition $\mathrm{G}$ without a bentonite addition $\left(\rho_{\mathrm{r}}=91.2 \%\right)$. From Table IV, it can be seen that, when the holding time at $1125{ }^{\circ} \mathrm{C}$ was increased from 10 to $60 \mathrm{~min}$, the relative density and the deep abrasion resistance increased from 93.6 to $94.1 \%$ and from 65 to 56 $\mathrm{mm}^{3}$, respectively. The small increase in relative density promoted a significant improvement in the bending strength, from 153 to $220 \mathrm{MPa}$. This probably occurred due to the longer holding time used at a given selected temperature, decreasing the viscosity of the liquid phase (matrix) and leading to densification.

When the sintering temperature was increased from 1125 to $1150{ }^{\circ} \mathrm{C}$, the material exhibited the highest relative density for a holding time of $10 \mathrm{~min}$, as previously reported. By increasing the temperature, more thermal energy is provided to the system, increasing the sintering rate, resulting in a higher densification in less time and improving the mechanical properties. In fact, the samples sintered at $1150^{\circ} \mathrm{C}$ for 10 min showed better results among the tested heat-treatment conditions, i.e., values of $51 \mathrm{~mm}^{3}$ and $222 \mathrm{MPa}$ for deep abrasion resistance and bending 

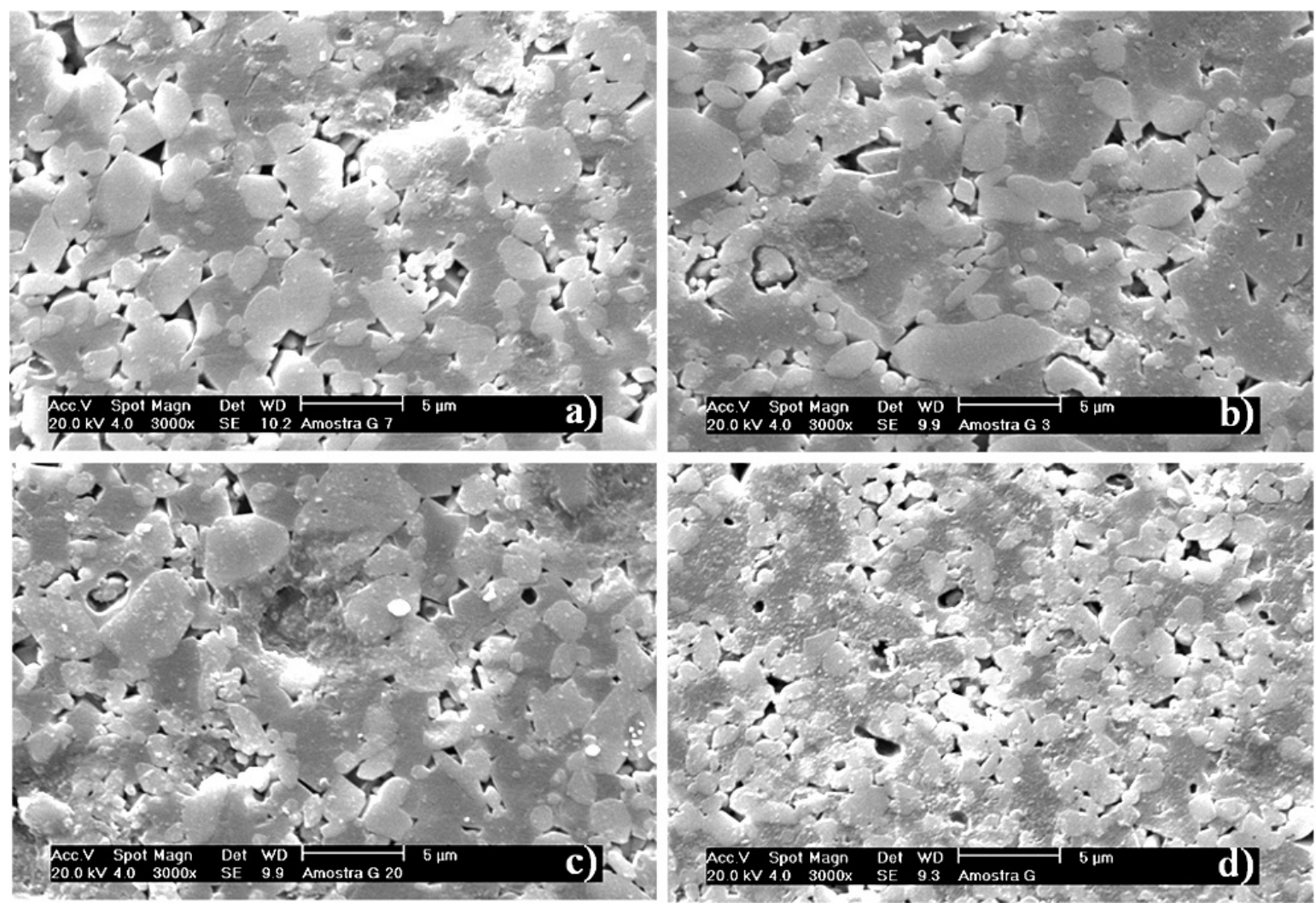

Figure 5: SEM micrographs of samples of composition G, sintered at 1125 (a), 1150 (b) and $1175^{\circ} \mathrm{C}$ (c) for 10 min and at $1175^{\circ} \mathrm{C}(\mathrm{d})$ for $60 \mathrm{~min}$. Not etched.

[Figura 5: Micrografias obtidas por microscopia eletrônica de varredura das amostras da composição G, sinterizadas a 1125 (a), 1150 (b) e $1175^{\circ} \mathrm{C}$ (c) por $10 \mathrm{~min}$ e a $1175^{\circ} \mathrm{C}$ (d) por $60 \mathrm{~min}$. Não atacadas.]

strength, respectively. However, when the holding time was increased from 10 to $60 \mathrm{~min}$ at $1150{ }^{\circ} \mathrm{C}$, the bending strength decreased, which is related to a porosity increase. The porosity increase was also observed when the sintering temperature was increased from 1150 to $1175{ }^{\circ} \mathrm{C}$, and the increase is more evident when the holding time increases. Moreover, densification in the LZSA glass powder started at approximately $640{ }^{\circ} \mathrm{C}$, and its rate was reduced at $700{ }^{\circ} \mathrm{C}$, likely due to the crystallization process. According to recent investigations [31-33], the crystallization in the LZSA system is surface-type; further, this crystallization behavior was expected due to the use of fine and high specific surface area powders. Additionally, when crystallization begins, the viscosity of the system increases, which causes a consequent decrease in the densification rate, because glass sintering occurs by viscous flow. After crystallization, the thermal linear shrinkage began to increase $\left(850^{\circ} \mathrm{C}\right)$ by reduction of the glassy phase viscosity as the temperature was increased. This new shrinkage occurred at $1150{ }^{\circ} \mathrm{C}$. The temperature increase resulted in material expansion, caused by the melting of the glass-ceramic matrix.

Fig. 5 shows micrographs of the samples sintered at 1125, 1150 , and $1175^{\circ} \mathrm{C}$ for $10 \mathrm{~min}$ and at $1175^{\circ} \mathrm{C}$ for $60 \mathrm{~min}$. The zircon particles exhibited good interaction with the glassceramic matrix, i.e., the zircon particles were sufficiently wetted by the matrix such that the formed interface exhibited a minimally visible porosity. The particles were homogeneously distributed over the glassy matrix for all observed samples. Therefore, to obtain composition $\mathrm{G}$ with optimized properties and high performance for a given application, the extruded compacts must be sintered at $1150{ }^{\circ} \mathrm{C}$ for $10 \mathrm{~min}$.

\section{CONCLUSIONS}

Extruded 60 wt. $\%$ zircon particulate-reinforced LZSA $\left(\mathrm{Li}_{2} \mathrm{O}-\mathrm{ZrO}_{2}-\mathrm{SiO}_{2}-\mathrm{Al}_{2} \mathrm{O}_{3}\right)$ glass-ceramic matrix composite with a $7 \mathrm{wt} . \%$ addition of bentonite as the binder, humidified with 23 wt.\% water was obtained by sintering and crystallization. After matrix crystallization, the densification was increased by reducing the glassy phase viscosity while increasing the temperature. A further temperature increase resulted in material expansion, caused by the melting of the glass-ceramic matrix. The microstructure consisted of fine crystals uniformly distributed and randomly oriented throughout the glassy phase as well as a residual porosity. The extruded composite samples, after sintering at $1150{ }^{\circ} \mathrm{C}$ for $10 \mathrm{~min}$, showed a thermal linear shrinkage of approximately $14 \%$, which corresponds to a relative density of $94.5 \%$, and deep abrasion resistance and bending strength of approximately $51 \mathrm{~mm}^{3}$ and $220 \mathrm{MPa}$, respectively. The measured coefficient of thermal expansion was relatively low for composition $\mathrm{G}$, indicating that the composite exhibited good thermal shock resistance. Finally, 
the extrusion technology is a potential candidate for the production of sintered glass-ceramic matrix composites for use in a number of applications.

\section{ACKNOWLEDGEMENTS}

The authors are grateful to CAPES and CNPq/Brazil for funding.

\section{REFERENCES}

[1] R. D. Rawlings, "Production and Properties of Silceram Glass Ceramics”, In: T. Manfredini, G. C. Pellacani, J. M. Rincón, Editors, Glass-Ceramic Materials: Fundamentals and Applications, Modena, Mucchi Editore (1997) 115-133. [2] Z. Strnad, "Glass-Ceramic Materials: Glass Science and Technology", vol. 8, Elsevier, Amsterdam, The Netherlands (1986.)

[3] W. Höland, G. Beall, "Glass-Ceramic Technology", Am. Ceram. Soc., Westerville, USA (2002).

[4] E. Rabinovich, Review: preparation of glass by sintering, J. Mater. Sci. 20 (1985) 4259-4297.

[5] I. Dlouhy, A. Boccaccini, Preparation, microstructure and mechanical-properties of metal-particulate glass-matrix composites, Compos. Sci. Technol. 56 (1996) 1415-1424.

[6] A. Boccaccini, M. Bucker, J. Bossert, K. Marszalek, Glass matrix composites from coal fly-ash and waste glass, Waste Manag. 17 (1997) 39-45.

[7] E. Bernardo, G. Scarinci, S. Hreglich, Mechanical properties of metal-particulate lead-silicate glass matrix composites obtained by means of powder technology, J. Eur. Ceram. Soc. 23 (2003) 1819-1827.

[8] V. Cannillo, G. Pellacani, C. Leonelli, A. Boccaccini, Numerical modeling of the fracture behavior of a glass matrix composite reinforced with alumina platelets, Compos. Part. A Appl. Sci. Manuf. 34 (2003) 43-51.

[9] V. Cannillo, T. Manfredini, M. Montorsi, A. Boccaccini, Investigation of the mechanical properties of Mo-reinforced glass-matrix composites, J. Non Cryst. Solids 344 (2004) 88-93.

[10] R. Ekici, M. Apalak, M. Yildirim, F. Nair, Effects of random particle dispersion and size on the indentation behavior of SiC particle reinforced metal matrix composites, Mater. Des. 31 (2010) 2818-2833.

[11] D. W. Richerson, "Modern Ceramic Engineering: Properties, Processing and Use in Design", $2^{\text {nd }}$ Ed., Marcel Dekker Inc., N. York, USA (1992).

[12] L. Giassi, D. Hotza, O. E. Alarcon, M. Fredel, A. P. N. Oliveira, Am. Ceram. Soc. Bull. 84 (2005) 9301-9307.

[13] A. P. N. Oliveira, E. Souza, C. B. Silveira, T. Fey, P. Greil, D. Hotza, LZSA glass ceramic foams prepared by replication process, Adv. Appl. Ceram. 104 (2005) 22-29.

[14] G. M. Reitz, O. R. K. Montedo, O. E. Alarcon, D. Hotza, A. P. N. Oliveira, Roll pressed LZSA glass-ceramics, Adv. Sci. Technol. 45 (2006) 442-446.

[15] C. R. Rambo, E. Sousa, A. P. N. Oliveira, D. Hotza, P. Greil, Processing of cellular glass ceramics, J. Am. Ceram.
Soc. 89 (2006) 3373-3378.

[16] C. M. Gomes, F. N. Biscaia, J. T. Quinaud, O. R. K. Montedo, A. P. N. Oliveira, D. Hotza, Aqueous tape casting of LZSA glass ceramics, Ceram. Trans. 193 (2006) 9-16.

[17] E. Souza, C. R. Rambo, D. Hotza, A. P. N. Oliveira, T. Fey, Low-temperature sintered LZSA cellular glass ceramics, Ceram. Trans. 193 (2006) 49-57.

[18] C. Silveira, J. Escobar, M. Quintero, E. Sousa, E. Moraes, A. P. N. Oliveira, C. R. Rambo, D. Hotza, Decomposição térmica de espumas de poliuretano para fabricação de vitrocerâmica celular de $\mathrm{Li}_{2} \mathrm{O}-\mathrm{ZrO} \mathrm{O}_{2}-\mathrm{SiO}_{2}-\mathrm{Al}_{2} \mathrm{O}_{3}$ (LZSA), Quim. Nova 30 (2007) 1104-1107.

[19] O. R. K. Montedo, F. M. Bertan, R. Piccoli, D. Hotza, A. N. Klein, A. P. N. Oliveira, Low thermal expansion sintered LZSA glass-ceramics, Am. Ceram. Soc. Bull. 87 (2008) 34-40.

[20] C. M. Gomes, A. P. N. Oliveira, D. Hotza, N. Travitzky, P. Greil, LZSA glass-ceramic laminates: fabrication and mechanical properties, J. Mater. Process. Technol. 206 (2008) 194-201.

[21] E. Sousa, C. R. Rambo, D. Hotza, A. P. N. Oliveira, T. Fey, P. Greil, Microstructure and properties of LZSA glassceramic foams, Mater. Sci. Eng. A Struc. Mater. 476 (2008) 89-97.

[22] T. Hausol, C. M. Gomes, H. Birol, A. P. N. Oliveira, D. Hotza, N. Travitzky, P. Greil, Glass-ceramics from LZSA cast tapes, J. Mater. Process. Technol. 210 (2010) 15561561.

[23] D. Hotza, A. P. N. Oliveira, New silicate glass-ceramic materials and composites, Adv. Sci. Technol. 68 (2010) 1-12.

[24] E. Ryshkewitch, D. W. Richerson, "Oxide Ceramics", $2^{\text {nd }}$ Ed., Haskell: General Ceramics, Inc.. Acad. Press, Orlando, USA (1985) p. 397-406.

[25] Y. Shi, X. Huang, D. Yen, Fabrication of hot-pressed zircon ceramics: mechanical properties and microstructure, Ceram. Int. 23 (1997) 457-462.

[26] M. Westwood, J. Webster, R. Day, F. Hayes, R. Taylor, Review: Oxidation protection for carbon fibre composites, J. Mater. Sci. 31 (1996) 1389-1397.

[27] J. S. Reed, "Firing: Principles of Ceramics Processing", John Wiley \& Sons, Inc., N. York, USA (1995).

[28] A. Barba, V. Beltrán, C. Feliú, J. García, F. Ginés, E. Sánchez, V. Sanz, "Clasificación de las Arcillas en Materias primas para la fabricación de soportes de baldosas cerâmicas", Instituto de Tecnología Cerámica - AICE, Castellón, Spain (1997).

[29] F. Bertan, O. R. K. Montedo, C. R. Rambo, D. Hotza, A. P. N. Oliveira, Extruded $\mathrm{ZrSiO}_{4}$ particulate-reinforced LZSA glass-ceramics matrix composite, J. Mater. Process. Technol. 209 (2009) 1134-1142.

[30] R. L. Fullman, Measurement of particle sizes in opaque bodies, Trans. AIME, J. Metals 197 (1953) 447-452.

[31] O. R. K. Montedo, D. Hotza, A. P. N. Oliveira, R. Meszaros, N. Travitzky, P. Greil, Crystallisation kinetics of a $\beta$-spodumene-based glass ceramic, Adv. Mater. Sci. Eng. V. 2012, ID 525428 (2012) 8 p. 
[32] O. R. K. Montedo, F. Floriano, J. Oliveira Filho, C. M. Gomes, D. Hotza, A. P. N. Oliveira, Sintering kinetics of a $18.8 \mathrm{Li}_{2} \mathrm{O}-8.3 \mathrm{ZrO}_{2}-64.2 \mathrm{SiO}_{2}-8.7 \mathrm{Al}_{2} \mathrm{O}_{3}$ glass ceramic, Ceram. Int. 37 (2011) 1865-1871.
[33] O. R. K. Montedo, F. J. Floriano, J. Oliveira Filho, E. Angioletto, A. M. Bernardin, Sintering behaviour of LZSA glass-ceramics, Mater. Res. 12 (2009) 197-200.

(Rec. 14/10/2012, Ac. 28/12/2012) 